\title{
Breeding system and inbreeding depression in the rare orchid Platanthera praeclara in a fragmented grassland landscape
}

\begin{tabular}{|c|c|}
\hline Journal: & Botany \\
\hline Manuscript ID & cjb-2017-0104.R2 \\
\hline Manuscript Type: & Article \\
\hline Date Submitted by the Author: & 29-Nov-2017 \\
\hline Complete List of Authors: & $\begin{array}{l}\text { Travers, Steven; North Dakota State University, Biological Sciences } \\
\text { Anderson, Kirk; North Dakota State University, Entomology } \\
\text { Vitt, Pati; Chicago Botanic Garden } \\
\text { Harris, Marion; North Dakota State University, Entomology }\end{array}$ \\
\hline $\begin{array}{r}\text { Is the invited manuscript for } \\
\text { consideration in a Special } \\
\text { Issue? : }\end{array}$ & N/A \\
\hline Keyword: & $\begin{array}{l}\text { plant conservation, inbreeding, self-pollination, orchid, plant breeding } \\
\text { systems }\end{array}$ \\
\hline
\end{tabular}

\section{SCHOLARONE ${ }^{m}$ \\ Manuscripts}


Breeding system and inbreeding depression in the rare orchid Platanthera praeclara in a fragmented grassland landscape Steven E. Travers ${ }^{1}$, Kirk Anderson ${ }^{2}$, Pati Vitt ${ }^{3}$ and Marion O. Harris ${ }^{2}$

1. S. Travers, Biological Sciences, Dept. 2715 , North Dakota State University, PO Box 6050, Fargo, ND 58108-6050, steven.travers@ndsu.edu

2. K. Anderson, M.O. Harris Entomology, Dept. 7650, North Dakota State University, PO Box 6050, Fargo, ND 58108-6050, kirk.anderson@ndsu.edu, marion.harris@ndsu.edu

3. P. Vitt, Chicago Botanic Garden, 1000 Lake Cook Road, Glencoe, IL 60022 , PVitt@chicagobotanic.org

Author for Correspondence: Steven Travers, steven.travers@ndsu.edu, 701231-9435 


\begin{abstract}
An important consequence of self-compatibility in plants is that self-pollination can have deleterious effects on plant fitness due to inbreeding. We conducted a hand pollination experiment under field conditions to measure the magnitude of inbreeding depression associated with self-pollination in the rare western prairie fringed-orchid Platanthera praeclara Sheviak and Bowles. By comparing capsules and seeds resulting from cross versus self-pollination treatments, we determined that self-pollination reduces seed quality while having no detectable effect on capsule production or seed numbers. A smaller percentage of seeds resulting from self-pollination contained an embryo $(18 \%)$ relative to seeds from cross-pollination (46\%). Seeds that had an embryo were scored for the size of the embryo, small or large. A smaller proportion of seeds from self-pollination contained a large embryo (75\%) relative to seeds from cross-pollination (92\%). These results suggest that sexual reproduction and recruitment in this rare plant are dependent on the frequency of pollinator visitations that result in outcrossing.
\end{abstract}

Keywords: plant conservation, plant breeding systems, inbreeding, selfpollination, orchid 


\section{Introduction}

Theory regarding the genetics of plant populations has provided predictions regarding the consequences of increasing rarity, particularly for those species in which habitat loss and fragmentation contribute to decreases in population size over time (Brook et al. 2002; Garnier et al. 2012). For small and declining populations, one potential risk to long-term population viability is an increase in the probability of inbreeding (Gilpin and Soule 1986; Menges 1991). Smaller populations of plants are at greater risk of inbreeding relative to large populations because, in situations of limited seed or pollen dispersal, mating among relatives (biparental inbreeding) is more likely (Ellstrand and Elam 1993). Inbreeding can also result from self-pollination in those plant species that do not have mechanisms for preventing self-fertilization. Inbreeding in turn can have greater effects on small populations by more rapidly reducing heterozygosity, decreasing genetic diversity and limiting potential long-term viability under changing conditions (Barrett et al. 1991). Inbreeding could also lead to reduced fitness of individuals through increased expression of recessive deleterious alleles (Charlesworth and Charlesworth 1987; Charlesworth and Willis 2009). Fitness consequences of inbreeding through self-pollination and bi-parental inbreeding have been predicted to contribute to population declines and "extinction vortices" whereby rare species reach a point of no return on the path to extinction (Gilpin and Soule 1986). 
We compared the fitness consequences of self- and cross-pollination in a rare orchid species to better understand the extent to which inbreeding is contributing to the decline of this species. The western prairie fringed orchid (Platanthera praeclara Sheviak and Bowles) is federally listed as threatened in both the United States and Canada (US Fish and Wildlife Service 1989; Environment Canada 2006). It was once common throughout the central grasslands region of North America, with populations ranging from Oklahoma to Manitoba (US Fish and Wildlife Service 2009; Center for Plant Conservation 2013,). Only three regional assemblages remain, one in southeastern North Dakota, another in northwestern Minnesota, and the third in southern Manitoba. As in many orchids, recruitment in P. praeclara is very likely limited by environmental conditions (e.g. hydrology, soil nutrition, mycorrhizal community composition) for establishment (Currah et al. 1990; Sharma et al. 2003a, b; Bleho et al. 2015). Loss of habitat has occurred because of agricultural development of the native range of the species during the past 150 years.

Many orchid species rely on pollinators for sexual reproduction (Bernhardt and Edens-Meier 2010). Autogamy is not common among plants in this family but Catling (1990) has suggested that between $5 \%$ and $20 \%$ of orchid species may have evolved autogamy. Self-incompatibility is also not common in orchids (Tremblay et al. 2005) suggesting that self-pollination by geitonogamy, where pollen is transferred between flowers on an individual plant, can account for a proportion of the seeds produced by most orchids. A review of 69 studies indicated that on average there was a $21 \%$ decrease in seed set associated with 
self-pollination relative to outcross pollination and that evidence of inbreeding depression in seeds was particularly acute in outcrossing species (Tremblay et al. 2005). Hawkmoths have been observed transferring pollen both between plants and within plants (Johnson et al. 2005, 2009; Xiong et al 2015). Thus, geitenogamy may be a source of negative effects on fitness through inbreeding depression.

Platanthera praeclara was originally described by Sheviak and Bowles (1986) as a hawkmoth-pollinated plant with an inflorescence that produces between one and 24 hermaphroditic and self-compatible flowers (Figure 1). Because hermaphroditic flowers mature pollinia and stigma simultaneously and multiple flowers of the inflorescence are open and receptive at the same time, there is opportunity for self-pollination. Pollinaria of $P$. praeclara have been found on the compound eyes of eight hawkmoth (Lepidoptera: Sphingidae) species (Cuthrell 1994; Westwood and Borkowsky 2004; Jordan et al. 2006; Fox et al. 2013; K. Anderson unpublished data). Pollinators visit flowers for their significant nectar reward (up to $20 \mu \mathrm{l}$ per flower, Fox et al. 2015) deployed in a 50-mm long nectar spur, which is also visited by nectar larcenists, including bees and longtongued hawkmoths (Fox et al. 2015). Orchid pollinaria become attached to the compound eye of the pollinator during nectar-feeding, which also is when pollen is delivered. Three signs of pollinator visitation are: pollinarium removal, pollen delivery to the stigma, and deposition of moth scales on the stigma. Of 269 plants surveyed from 2004 to $2007,80 \%$ of those showing all three signs produced seed capsules (Fox et al. 2013). Native and introduced hawkmoth 
species have been filmed carrying $P$. praeclara pollinia between flowers within an inflorescence and also between plants (https://www.ndsu.edu/entomology/research/videos/).

Previous studies of P. praeclara suggest that individuals produce a fraction of the seeds they could potentially produce. Its protected status limits the measures and experimental manipulations that are allowed on public lands, where most individuals are located. Monitoring the status and persistence of $P$. praeclara populations is typically carried out by scoring numbers of flowering plants in July. Sometimes the plants that flowered in midsummer are visited again in autumn to determine the percentage of flowers that produced a seed capsule. Capsule diameter of $3 \mathrm{~mm}$ is considered the threshold for scoring successful reproduction (Alexander 2006). The ongoing long-term survey of $P$. praeclara and its pollinators in southeastern North Dakota indicates that that orchid populations are pollen limited (Fox et al. 2013; Harris and Anderson, unpublished data). Median fruit set per flower was $18 \%$. Over a third of all plants did not produce any capsules. Evidence of post-dispersal pollination failure came from the fact that $40 \%$ of flowers that received pollen failed to produce a seed capsule (Fox et al. 2013).

Only rarely have investigators working on public lands been allowed to remove $P$. praeclara capsules in order to investigate the viability seeds they contain. Permission was given to collect a total of 45 open-pollinated seed capsules over a two-year period to determine if morphometric measures of capsule dimension could be used to predict seed quantity (Alexander 2006; 
Alexander et al. 2010). This study concluded that the two non-destructive capsule measurements that are allowed, i.e. diameter and length, are not useful for predicting the number of seeds in the capsule or the proportion of seeds that contain an embryo. It was not known whether the open-pollinated capsules that were examined in this study resulted from self or cross-pollination.

Our goals were to: 1) determine the influence of self- versus crosspollination on the number of seeds produced by hand-pollinated flowers and their viability, as measured by presence and size of embryos, 2) determine whether seed capsule size differs between self-pollinated and cross-pollinated fruits, and 3) compare levels of $P$. praeclara inbreeding depression to other related orchids. The hand pollination experiments were conducted on private land, with the permission of the landowner.

\section{Methods}

Hand-pollination experiment

We collected data on field-grown plants in natural populations located at two sites in Ransom County, North Dakota over the course of two summers (2011 and 2012). Experimental plants were in typical $P$. praeclara habitat: grassy swales with standing water at the lowest points (Sheviak and Bowles 1986). Soils in these regions are sandy and the surrounding plant community is tallgrass prairie. Identifying characteristics of research sites, including Global Positioning coordinates, cannot be published due to the threats from poachers of rare 
orchids. All field sites used in this study have never been plowed, but have been grazed and/or hayed for at least the last ten years.

In the summer of 2011 , we located $P$. praeclara plants during the bud stage $^{1}$. The orchids were at two sites designated North or South, which were separated by approximately $1.4 \mathrm{~km}$ of prairie. At the North and South sites, 70 and 50 flowering orchids were located, respectively. The average distance between plants was between one and five meters. At each site, we selected 30 plants that had a minimum of three floral buds per inflorescence that were at the same stage of maturation, a requirement for the complete block experimental design. We marked plants with metal tags staked to the ground a half meter away with galvanized roofing nails. Each of three unopened flower buds on each plant was labeled with a jeweler's tag around the pedicel that identified the treatment assigned to the flower. The three pollination treatments were: 1) crosspollination, 2) self-pollination, or 3) unpollinated. The unpollinated treatment was the control treatment, but also determined if flowers produce fruits autogamously under the conditions of our experiment. In order to randomize the treatment of flowers within the inflorescence, we assigned the lowest bud on each plant to a different treatment from the previous two plants and then followed the same sequence of treatments up the inflorescence (self, cross, unpollinated).

Several days later, when all three flowers on experimental plants had

\section{Supplementary Materials, Table S1}


opened (they were covered with tule bags after labelling), we collected mature pollinaria from randomly selected non-experimental plants from each of the two populations. Pollinaria were individually placed in labeled microcentrifuge tubes and kept in a cooler. For each experimental plant, the mesh bag was removed from the inflorescence. The cross-pollination treatment was accomplished by removing a single pollinarium from a microcentrifuge tube of the alternate population (North or South) and smearing the pollinarium across the focal stigma until it was visibly covered with yellow pollen. Self-pollinations were accomplished by removing a pollinarium from the same flower and applying its pollen to the stigma of the same flower. For the unpollinated treatment, no pollen was applied to the stigma.

Ten days after pollination treatments were applied, we measured the diameter and length of ovaries from all experimental flowers using a hand-held caliper (0-150 mm digital caliper, Maryland Metrics Electronic Digital Caliper, Owings Mills, MD). Since cattle had been introduced into the areas where experimental plants were located we set up exclosures to protect experimental plants. However, our efforts to protect our experimental plants were restricted by the limited availability of livestock panels $(1.22 \mathrm{~m} \times 1.22 \mathrm{~m} \times 1.22 \mathrm{~m})$. As a result, cattle subsequently destroyed many of the experimental plants.

Mature capsules were collected from the field as they began to turn brown. We placed each capsule in a labeled shell vial $(25 \times 80 \mathrm{~mm})$ that was closed with a plastic snap-on lid. In the laboratory, the plastic lid was replaced with another that had a mesh insert, which allowed moisture to escape. Capsules 
were kept in the laboratory at room temperature for 2-3 weeks. We then measured: 1) the mass of each fruit, and 2) the mass of the fruit with its seeds removed, in order to calculate 3) the mass of the fruit's total seeds. A sub-sample of seeds from each self and outcross fruit was taken for a determination of mass. Prior to sampling the fruits were agitated by hand to mix their contents. A haphazardly determined volume of seeds was removed from each fruit with a paintbrush and placed on a microscope slide where they were counted (range $=$ 88 to 218 seeds, average $=112.5$ seeds per capsule). The subsample was then weighed to extrapolate the number of seeds per capsule. The seed coat of $P$. praeclara is transparent (Figure A1). Each seed in the sub-sample was examined for the presence of an embryo with a $25 \mathrm{X}$ dissecting scope according to the methodology of Alexander (2006). Each seed was assigned to one of three categories: no embryo, small embryo, or large embryo. No embryo meant there was no visible embryo within the seed coat. Small embryo meant the embryo took up half or less of the interior space of the seed (Appendix 1, Figure A1). Large embryo meant the embryo took up more than half of the interior space of the seed. All seeds produced by an individual plant were returned to the original site of the plant and scattered around the base of that plant.

The experiment was repeated in the summer of 2012, when fewer plants were available. None of the 8 plants at the South site had three flowers at a suitable stage for the experiment. Out of the 24 flowering plants present at the North site, only four plants met these requirements. For the most part, methods were similar to those used in 2011. The scarcity of orchids at the South site 
necessitated a change in sourcing outcross pollen, which in 2012 came from a smaller roadside $P$. praeclara population that was approximately $200 \mathrm{~m}$ away due west of the orchids at the South Site and $1.4 \mathrm{~km}$ from the North Site. The four 2012 experimental plants at the North Site were protected from grazing cattle with the same livestock exclosures used in 2011. Capsules were collected as they began to turn brown. In the laboratory, counts of the subsamples of seeds from self and outcross capsules ranged from 74 to 193 seeds (average $=$ 142.2 seeds/capsule). Since the weight of the subsample was not taken in 2012 , we were not able to estimate total seed number or average mass per seed.

\section{Statistical analyses}

Statistical analyses were performed using the program $\mathrm{R}$, version 2.13.2 (R Development Core Team, 2010). Each plant was treated as a block to control for genetic and maternal effects. Prior to statistical analysis, we tested for differences between years in dependent variables collected in both years using ANOVA. None of the seed or fruit variables had a significant year effect so we pooled the data from 2011 and 2012 with the exception of total number of seeds and mass of individual seeds since these variables were only measured in 2011 . The index of inbreeding depression $(\underline{\delta})$ was calculated for each variable as the difference between self and outcross treatments divided by the outcross value (Charlesworth and Charlesworth 1987). In order to examine relationships between capsule and seed characteristics, we conducted a correlation analysis on data from the self and cross-pollination treatments separately, analyzing the relationship between total seed mass, the proportion of seeds per capsule with 
embryos, and capsule diameter or length. We used paired $t$-tests to compare treatment effects while controlling for among-plant variation. Data from plants without both self and outcross capsules were excluded from the analysis.

\section{Results}

Ovaries of flowers that did not receive pollen failed to increase in length or diameter over the course of the growing season (Table 1). In contrast, ovaries of flowers that were hand-pollinated with either self or outcross pollen grew, as measured by diameter and length. Average final diameter of capsules was not different for self- and cross-treatments ( $4.6 \pm 0.2$ and $4.4 \pm 0.1$, respectively). There was also no difference between the two treatments in mean capsule length (Table 1).

Seed production differed across the three pollination treatments. Flowers assigned to the unpollinated treatment failed to produce an enlarged capsule or any seeds (Figure 2 , Table 1 ). The self- and cross-treatments produced both a capsule and a large number of seeds, estimated to range from 5,700 to 36,500 seeds per capsule (Figure 2). There was no difference in estimated seed number per capsule between the self- and cross-treatments (Figure 2, $t=0.25, p>0.05$ ). A smaller percentage of seeds $\left(t=1.2, p<0.001^{*}\right)$ resulting from self-pollination contained an embryo (18\%) relative to seeds from cross-pollination (46\%, Figure 3A). A smaller proportion of seeds from self-pollination contained a large embryo $(75 \%)$ relative to seeds from cross-pollination (92\%) (Figure 3B; $t=1.4 ; p<0.001$ ). Total seed mass $\left(t=1.1, p<0.001^{*}\right)$ and estimated mass per seed $(t=0.45$, 
$\left.p<0.001^{*}\right)$ for the self- treatment were 36 and $38 \%$ lower than those of the crosstreatment (Table 1).

Pollination treatment influenced relationships between measures of capsules and seeds. Capsule diameter was positively correlated with seed mass for both self and cross-pollinated flowers (Table 2, Figure 4) but was positively correlated with the proportion of seeds with embryos only for the cross-treatment (Table 2). Seed mass was positively correlated with the proportion of seeds with embryos for the cross- but not the self-treatment (Table 2). Capsule length showed no relationship to the other three measures (Table 2). In general (Figure 4), capsule diameter was positively correlated with total seed mass $\left(R^{2}=0.76\right.$, $F=141.6, p<0.001)$, as well as proportion of seeds with an embryo $\left(R^{2}=0.45\right.$, $F=41.4, p<0.001)$.

\section{Discussion}

Consequences of self- versus cross-pollination

The results of the experiment lead us to conclude that outcrossing has a major impact on the quality of $P$. praeclara seeds. Although the production of capsules was independent of pollen source, the content of those capsules depended strongly on whether plants were self-pollinated or outcrossed On average, outcrossing produced a greater percentage of seeds having an embryo, as well as a greater proportion of seeds having a larger embryo (Table 1, Figure $3 \mathrm{~A}, \mathrm{~B})$. These reductions in seed quality with self-pollination are consistent with early acting inbreeding depression. It is important to note that our comparison 
was between seeds produced from self-pollination and from outcross pollen in a different population which is a more extreme comparison than with seeds from pollinations within the population. However, we expect that the magnitude of inbreeding depression measured was not magnified artificially because of the proximity of the two populations $(1500 \mathrm{~m})$. Genetic evidence that divergence between populations is very weak, even across much broader scales (e.g. 200 km; Ross and Travers 2015).

What is a viable seed? Seed mass is commonly used as a correlate of seed viability (e.g. Jersakova et al. 2006) but $P$. praeclara seeds are too small to weighed individually. Attempts to germinate P. praeclara seeds have had limited success and staining of seeds to determine viability was unsuccessful (Marge From, personal communication). In P. leucophaea, the orchid's sister species, Wallace (2003) concluded that self-pollination results in a significant decrease in seed mass and an absence of large embryos. Based on the assumption that the presence of large embryos correlated with seed viability, Wallace (2003) came up with estimates of inbreeding depression ranging from 0.17 to 0.74 . Inbreeding depression estimates in two other Platanthera species (bifolia and chlorantha) were 0.48 and 0.68 respectively (Nilsson 1983). A review of studies in 31 species of orchids (Smithson 2006) indicated that inbreeding depression is much more likely to manifest in later stages of reproduction (e.g. seed viability) than earlier stages (e.g. fruit production). Inbreeding depression estimates based on seed mass and viability in these species ranged from -0.06 to 0.71 and averaged 0.37 . Reductions in overall seed quality associated with pollination by self-pollen 
relative to cross pollen are consistent with inbreeding depression that occurs prior to seed germination and seedling growth (Charlesworth and Charlesworth 1987). Our study focused on a single pair of relatively small populations. It is unclear to what degree the relative effects of inbreeding and outbreeding will have across a range of larger populations. However, inbreeding levels tend to go down in larger populations of $P$. praeclara (Ross and Travers 2015). In these populations where inbreeding is relatively rare it may be that the effects of on fitness are even greater.

Platanthera praeclara is a federally threatened species in both the United States and Canada. Monitoring the genetic health of populations is essential. Given that individual plant fitness is strongly influenced by outcrossing, we had hoped to find a non-destructive morphological measurement of seed capsules that would allow land managers to estimate of the incidence of outcross versus self-pollination on a per flower and per plant basis. Heretofore, the assumption has been that all capsules achieving a minimum diameter of $3 \mathrm{~mm}$ have produced viable seeds. We discovered that the rate of capsule development and final measures of size (diameter, length or relationships between diameter and length) did not differ between self-and cross-pollination treatments (Table 1). Thus, we failed to identify a non-destructive method for land managers to assess the proportion of seed capsules that contain less viable seeds due to selfpollination rather than cross-pollination.

\section{Pollinator behavior and self-pollination}


Platanthera praeclara is dependent on pollinators for sexual reproduction. Sheviak and Bowles (1986) proposed that $P$. praeclara has a mixed mating system in spite of being adapted to promote outcrossing, evidence being an energetically-costly floral display, long nectar spur and large nectar volume. For each of the eight hawkmoth pollinator species of P. praeclara (Cuthrell 1994; Westwood and Borkowsky 2004; Jordan et al. 2006; Fox et al. 2013; K. Anderson unpublished data), it is likely that interactions with nectar play a key role in determining the level of geitonogamy. Johnson et al. (2005) studied a hawkmoth-pollinated orchid in Africa (Disa cooperi) that is similar to P. praeclara in having a long nectar spur and a relatively large amount of nectar deployed in flowers grouped in a tall inflorescence. They found that pollen tended to move only a few meters (median $=2.5 \mathrm{~m}$ ). There also is evidence that the time that hawkmoth pollinators devote to exploring individual flowers, as well as the entire inflorescence, depends on the magnitude of nectar reward per flower and the distribution of rewards across the inflorescence. Hodges (1995) found that hawkmoth pollinators of Mirabilis multiflora devoted more time to intraplant foraging rather than interplant foraging as nectar reward per flower was increased experimentally across the inflorescence. In $P$. praeclara, nectar rewards are highly variable across the flowers that comprise a single inflorescence, regardless of whether the inflorescence has been accessible to pollinators (Fox et al. 2015). It was proposed that the uneven distribution of rewards across the inflorescence is an adaptation for promoting outcrossing. 
Population genetic studies of both the western (Ross and Travers 2015; Tennefos unpublished data) and the eastern prairie fringed orchid (Paul, Budd and Freeland 2013) support the conclusion that inbreeding is common in these species. Analyses of population patterns of molecular markers in both species found relatively high degrees of homozygosity regardless of population size ( $P$. praeclara: average $F_{I S}=0.23 ; P$. leucophaea: average $F_{I S}=0.31$ ) and inbreeding coefficient values (Table 1) that are typical for species where self-pollination and biparental inbreeding are common.

Outbreeding depression is a concern in a species with the potential for long distance pollen dispersal by hawkmoths. However, outbreeding depression does not seem likely given the evidence we have from genetic studies. Analyses of genetic structure among populations (Ross and Travers 2015) up to $200 \mathrm{~km}$ apart found relatively low levels of divergence $(G s t=0.08)$. Previous studies found similar results (Sharma 2002; Pleasants and Klier 1995). In the absence of evidence for ecotypic differentiation among even these distant populations, we predict that inbreeding depression is more important than outbreeding depression in this species.

Overall, the results of this study suggest that a potential limitation on the population growth of this rare species is limited cross-pollination and production of viable seeds. Self-pollination undoubtedly occurs and potentially at high rates. In addition, it is likely that many flowers are not sufficiently pollinated (transfer of fewer pollen grains than ovules in ovary) with outcross pollen. However, low production of viable seeds represents an additional restriction on population 
growth through the limits it creates for adding new and genetically-varied recruits. Future management of $P$. praeclara population would benefit from a discussion about what can be done to increase levels of outbreeding, including the creation of corridors of alternate nectar plants that, by connecting small and large populations of $P$. praeclara, encourage hawkmoth pollinators to range more freely across the landscape. Encouraging land managers to create habitat for pollinators is also essential (Fox et al. 2013, 2015). 


\section{Acknowledgements}

We thank the Nature Conservancy, the United States Department of Agriculture, and ranchers for allowing us to study orchids on their land since 2002. Funding was provided by a grant from the San Diego County Orchid Society. We thank Marge From (Henry Doorly Zoo, Omaha, NE) for comments on an earlier draft of the manuscript and for providing essential information regarding seed development, viability and propagation for Platanthera praeclara and orchids in general. 


\section{Literature Cited}

Alexander, B., Kirby, D., Biondini, M., and Dekeyser, E. 2010. Cattle grazing reduces survival and reproduction of the western prairie fringed orchid. Prairie Nat. 42: 46-49.

Alexander, B. J. W. 2006. An analysis of seed production, viability, germination in situ, and grazing impacts on the western prairie fringed orchid (Platanthera praeclara, Sheviak and Bowles) Ph.D., North Dakota State University.

Barrett, S. C. H., and Kohn, J. R. 1991. Genetic and evolutionary consequences of small population size in plants: Implications for conservation. In Genetics and Conservation of Rare Plants. Edited by D. Falk and K. E. Holsinger. Oxford University Press, New York.

Bernhardt, P., and Edens-Meier, R. 2010. What we think we know vs. what we need to know about orchid pollination and conservation: Cypripedium $\mathrm{L}$. as a model lineage. Bot. Rev. 76: 204-219.

Bleho, B. I., Koper, N., Borkowsky, C. L., and Hamel, C. D. 2015. Effects of Weather and Land Management on the Western Prairie Fringed-orchid (Platanthera praeclara) at the Northern Limit of its Range in Manitoba, Canada. Am. Midl. Nat. 174: 191-203.

Brook, B. W., Tonkyn, D. W., O'Grady, J. J., and Frankham, R. 2002. Contribution of inbreeding to extinction risk in threatened species. Conserv. Ecol. 6: 16. 
Catling, P. M. 1990. Auto-pollination in the Orchidaceae. In Orchid biology: reviews and perspectives. Edited by A. J. Timber Press, Portland, OR. pp. $121-158$.

Charlesworth, D., and Charlesworth, B. 1987. Inbreeding depression and its evolutionary consequences. Annu. Rev. Ecol. Syst. 18:237-268.

Charlesworth, D., and Willis, J. H. 2009. The genetics of inbreeding depression. Nat. Rev. Genet. 10: 783-796.

Center for Plant Conservation. 2013. CPC National collection plant profile. Missouri Botanical Garden. St. Louis, MO.

Culley, T. M., Weller, S. G., Sakai, A. K., and Rankin, A. E. 1999. Inbreeding depression and selfing rates in a self-compatible, hermaphroditic species, Schiedea membranacea (Caryophyllaceae). Am. J. Bot. 86: 980-987.

Currah, R. S., Smreciu, E. A., and Hambleton, S. 1990. Mycorrhizae and mycorrhizal fungi of boreal species of Platanthera and Coeloglossum (Orchidaceae). Can. J. Bot. 68: 1171-1181.

Cuthrell, D. L. 1994. Insects associated with the prairie fringed orchids Platanthera praeclara Sheviak \& Bowles and P. Leucophaea (Nuttall) Lindley. M.Sc. thesis, North Dakota State University Fargo, ND.

Ellstrand, N., and Elam, D. 1993. Population genetic consequences of small population size: Implications for plant conservation. Annu. Rev. Ecol. Evol. Syst. 24: 217-242. 
Environment Canada. 2006. Recovery strategy for the western prairie fringed orchid (Platanthera praeclara) in Canada, vol 22. In Species at risk act recovery strategy series. Environment Canada, Ottawa.

Fox, K., Vitt, P., Anderson, K., Fauske, G., Travers, S., Vik, D., and Harris, M. O. 2013. Pollination of a threatened orchid by an introduced hawk moth species in the tallgrass prairie of North America. Biol. Conserv. 167: 316324.

Fox, K., Anderson, K., Andres, B., Foster, M. C., Foster, C. E., Vik, D., Vitt, P., and Harris, M. O. 2015. Nectar robbery and thievery in the hawk moth (Lepidoptera: Sphingidae)-pollinated western prairie fringed orchid (Platanthera praeclara). Ann. Entomol. Soc. Am. 108: 1000-1013.

Garnier, J., Roques, L., and Hamel, F. 2012. Success rate of a biological invasion in terms of the spatial distribution of the founding population. B. Math. Biol. 74: 453-473.

Gilpin, M. E., and Soule, M. E. 1986. Minimum viable populations: processes of species extinction. In Conservation Biology: the science of scarcity and diversity. Sinauer Associates, Sunderland, MA. pp. 19-34.

Hodges, S. A. 1995. The Influence of Nectar Production on Hawkmoth Behavior, Self Pollination, and Seed Production in Mirabilis multiflora (Nyctaginaceae). Am. J. Bot. 82: 197-204.

Husband, B. C., and Schemske, D. W. 1996. Evolution of the magnitude and timing of inbreeding depression in plants. Evolution, 50: 54-70. 
Jersakova, J., Johnson, S. D., and Kindlmann, P. 2006. Mechanisms and evolution of deceptive pollination in orchids. Biol. Rev. 81: 219-235. Johnson, S. D., Neal, P. R., and Harder, L. D. 2005. Pollen fates and the limits on male reproductive success in an orchid population. Biol. J. Linn. Soc. 86: $175-190$.

Johnson, S. D., Torninger, E., and Agren, J. 2009. Relationships between population size and pollen fates in a moth-pollinated orchid. Biol. Lett. 5: 282-285.

Jordan, C., Fauske, G., Harris, M. O., and Lenz, D. 2006. First record of the spurge hawk moth as a pollen vector for the western prairie fringed orchid. Prairie Nat. 38: 63-66.

Lande, R., and Schemske, D. W. 1985. The evolution of self-fertilization and inbreeding depression in plants. I. Genetic models. Evolution, 39: 24-40. Menges, E. 1991. The applicatin of minimum viable population theory to plants. In Genetics and Conservation of Rare Plants. Edited by D. Falk and K. E. Holsinger. Oxford University Press, New York, NY.

Nilsson, L. A. 1983. Processes of isolation and introgressive interplay between Platanthera bifolia (L) Rich and Plantanthera chlorantha (Custer) Reichb (Orchidaceae). Bot. J. Linn. Soc. 87: 325-350.

Paul, J., Budd, C., and Freeland, J. R. 2013. Conservation genetics of an endangered orchid in eastern Canada. Conserv. Genet. 14: 195-204.

Pleasants, J. M., and Klier, K. 1995. Genetic variation within and among populations of the eastern and western praire fringed orchids, Platanthera 
leucophaea and P. praeclara. Report to the lowa Department of Natural Resources.

Ross, A. A., and Travers, S. E. 2015. The genetic consequences of rarity in the western prairie fringed orchid (Platanthera praeclara). Conserv. Genet. 17: 69-77.

R Development Core Team. 2010. R: A language and environment for statistical computing. Foundation for Statistical Computing. Vienna, Austria.

Sharma, J. 2002. Mycobionts, germination and conservation genetics of federally threatened Platanthera praeclara (Orchidaceae). PhD, University of Missouri.

Sharma, J., Zettler, L. W., and Van Sambeek, J. W. 2003a. A survey of mycobionts of federally threatened Platanthera praeclara (Orchidaceae) Symbiosis, 34: 317-318.

Sharma, J., Zettler, L. W., van Sambeek, J. W., Ellersieck, M. R. and Starbuck, C. J. $2003 b$. Symbiotic seed germination and mycorrhizae of federally threatened Platanthera praeclara (Orchidaceae). Am. Midl. Nat. 149: 104120.

Sheviak, C., and Bowles, M. 1986. The prairie fringed orchids: a pollinatorisolated pair. Rhodora, 88: 267-290.

Smithson, A. 2006. Pollinator limitation and inbreeding depression in orchid species with and without nectar rewards. New Phytol. 169: 419-430.

Tremblay, R. L., Ackerman, J. D., Zimmerman, J. K., and Calvo, R. N. 2005. Variation in sexual reproduction in orchids and its evolutionary 
consequences: a spasmodic journey to diversification. Biol. J. Linn. Soc.

84: 1-54.

US Fish and Wildlife Service. 1989. Endangered and threatened wildlife and plants: determination of threatened status for Platanthera leucophaea (eastern prairie fringed orchid) and Platanthera praeclara (western prairie fringed orchid) recovery plan. In Federal Register, 39857-62.

US Fish and Wildlife Service. 2009. Western prairie fringed orchid (Platanthera praeclara) 5-Year Review Summary and Evaluation. Bloomington Minnesota.

Wallace, L. E. 2003. The cost of inbreeding in Platanthera leucophaea (Orchidaceae). Am. J. Bot. 90: 235-242.

Westwood, A. R., and Borkowsky, C. L. 2004. Sphinx moth pollinators for the endangered western prairie fringed orchid, Platanthera praeclara in Manitoba, Canada. J. Lepid. 58: 13-20.

Xiong, Y. Z., Liu, C. Q,. and Huang, S. Q. 2015. Mast fruiting in a hawkmothpollinated orchid Habenaria glaucifolia: an 8-year survey. J. Plant Ecol. 8: $136-141$. 


\section{FIGURE CAPTIONS}

Figure 1. Inflorescence of Platanthera praeclara with mature flowers.

Figure 2. The estimated number of seeds per capsule (mean) from each of the three treatments in 2011 (mean + se).

Figure 3. A. Percentage of seeds in a capsule that exhibited an embryo for self and cross-pollinations (self vs. outcross: $t=1.2, p<0.001^{*}$ ). B. The percentage of seed coats with embryos that have either small (i.e. $<50 \%$ seed) or large embryos ( $>50 \%$ area of seed) by treatment (self vs. outcross: $t=1.4, p<0.001^{*}$ ).

Figure 4. Capsule diameter as a function of the total seed mass in the capsule by treatment. 
Table 1. Seed characteristics by pollination treatment.

\begin{tabular}{lcccccc}
\hline Treatment & Total seed & Estimated & Estimated & Proportion seeds & Cap. length & Cap. diam. \\
& mass $(\mathrm{mg})$ & \# seeds & Mass $/$ seed $(\mu \mathrm{g})$ & with an embryo & $(\mathrm{mm})$ & $(\mathrm{mm})$
\end{tabular}

Control

$\begin{array}{ccccccc}\text { Ave. } & 0 & 0 & 0 & 0 & 17.5 & 1.5 \\ \text { (SE): } & (0) & (0) & (0) & (0) & (0.62) & (0.30) \\ & 19: & 19 & 19 & 19 & 19 & 19\end{array}$

Self

$\begin{array}{ccccccc}\text { Ave. } & 9.8 & 16648 & 0.55 & 0.18 & 20.9 & 4.4 \\ \text { (SE): } & (1.0) & (1680) & (0.04) & (0.03) & (0.59) & (0.13) \\ \mathrm{N}: & 20 & 16 & 16 & 20 & 20 & 20\end{array}$

Outcross

$\begin{array}{rcccccc}\text { Ave. } & 15.7 & 16714 & 0.81 & 0.46 & 21.0 & 4.6 \\ \text { (SE): } & (2.1) & (1674) & (0.07) & (0.06) & (0.69) & (0.18) \\ \mathrm{N}: & 18 & 14 & 14 & 18 & 18 & 18\end{array}$

$\underline{\text { Inbreeding }}$ 
depression ( $\delta):$

0.38

0.003 
Table 2. Correlation coefficients between four fruit and seed characteristics for self and outcross pollinations. Coefficients are indicated above the diagonal line in each table ( ${ }^{*}$ indicates $P<0.05$ ); $p$-values for the test of significance are below the diagonal.

\section{Self pollinations}

\begin{tabular}{|c|c|c|c|c|c|c|c|c|}
\hline & $\begin{array}{l}\text { Capsule } \\
\text { length }\end{array}$ & $\begin{array}{l}\text { Capsule } \\
\text { diameter }\end{array}$ & $\begin{array}{l}\text { Total } \\
\text { seed } \\
\text { mass }\end{array}$ & $\begin{array}{c}\text { Proportion } \\
\text { seeds w/ } \\
\text { embryo }\end{array}$ & $\begin{array}{c}\text { Capsule } \\
\text { length }\end{array}$ & $\begin{array}{l}\text { Capsule } \\
\text { diameter }\end{array}$ & $\begin{array}{l}\text { Total } \\
\text { seed } \\
\text { mass }\end{array}$ & $\begin{array}{c}\text { Proportion } \\
\text { seeds w/ } \\
\text { embryo }\end{array}$ \\
\hline $\begin{array}{l}\text { Capsule } \\
\text { length }\end{array}$ & $x$ & 0.1 & 0.39 & 0.24 & $x$ & 0.08 & 0.37 & 0.11 \\
\hline $\begin{array}{r}\text { Capsule } \\
\text { diameter }\end{array}$ & 0.66 & $x$ & $0.83^{*}$ & 0.08 & 0.74 & $x$ & $0.81^{*}$ & $0.51^{*}$ \\
\hline $\begin{array}{l}\text { Total } \\
\text { seed } \\
\text { mass }\end{array}$ & 0.09 & 0.0 & 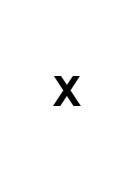 & 0.25 & 0.13 & 0.0 & X & $0.54^{*}$ \\
\hline $\begin{array}{l}\text { Proportion } \\
\text { seeds w/ } \\
\text { embryo }\end{array}$ & 0.32 & 0.74 & 0.29 & $x$ & 0.67 & 0.03 & 0.02 & $x$ \\
\hline
\end{tabular}

\begin{tabular}{|c|c|c|c|c|c|c|c|c|}
\hline & $\begin{array}{l}\text { Capsule } \\
\text { length }\end{array}$ & $\begin{array}{l}\text { Capsule } \\
\text { diameter }\end{array}$ & $\begin{array}{l}\text { Total } \\
\text { seed } \\
\text { mass }\end{array}$ & $\begin{array}{l}\text { Proportion } \\
\text { seeds w/ } \\
\text { embryo }\end{array}$ & $\begin{array}{l}\text { Capsule } \\
\text { length }\end{array}$ & $\begin{array}{l}\text { Capsule } \\
\text { diameter }\end{array}$ & $\begin{array}{l}\text { Total } \\
\text { seed } \\
\text { mass }\end{array}$ & $\begin{array}{c}\text { Proportion } \\
\text { seeds w/ } \\
\text { embryo }\end{array}$ \\
\hline $\begin{array}{l}\text { Capsule } \\
\text { length }\end{array}$ & $X$ & 0.1 & 0.39 & 0.24 & $x$ & 0.08 & 0.37 & 0.11 \\
\hline $\begin{array}{r}\text { Capsule } \\
\text { diameter }\end{array}$ & 0.66 & $x$ & $0.83^{*}$ & 0.08 & 0.74 & $x$ & $0.81^{*}$ & $0.51^{*}$ \\
\hline $\begin{array}{l}\text { Total } \\
\text { seed } \\
\text { mass }\end{array}$ & 0.09 & 0.0 & $x$ & 0.25 & 0.13 & 0.0 & $x$ & $0.54^{*}$ \\
\hline $\begin{array}{l}\text { Proportion } \\
\text { seeds w/ } \\
\text { embryo }\end{array}$ & 0.32 & 0.74 & 0.29 & $x$ & 0.67 & 0.03 & 0.02 & $x$ \\
\hline
\end{tabular}

\section{Outcross pollinations}




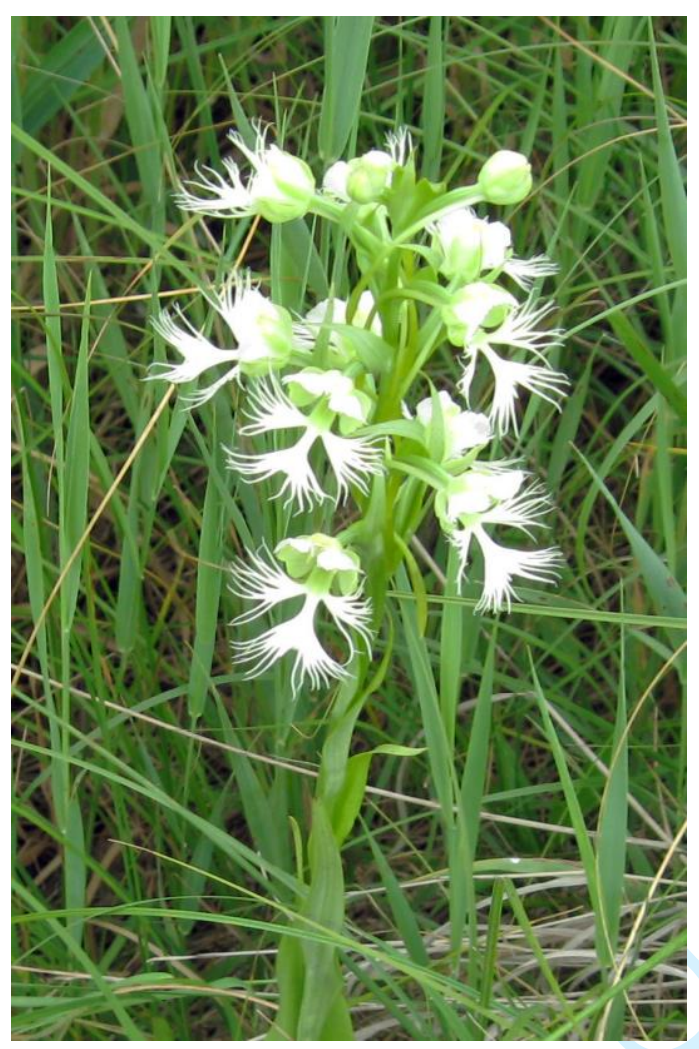

Figure 1. 


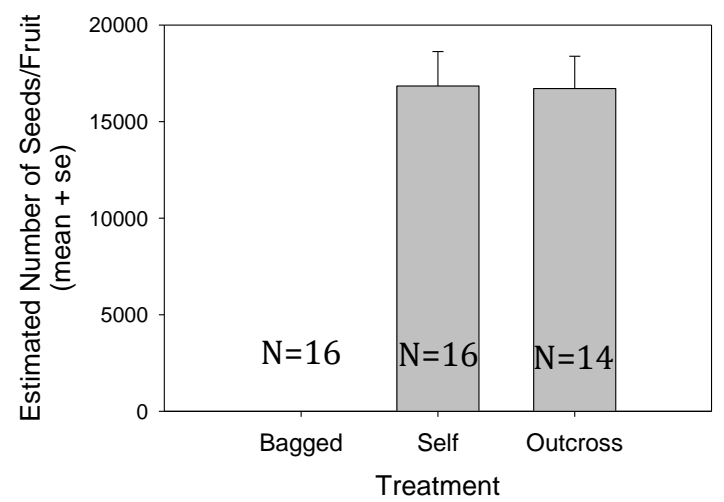

Figure 2.

https://mc06.manuscriptcentral.com/botany-pubs 
a)

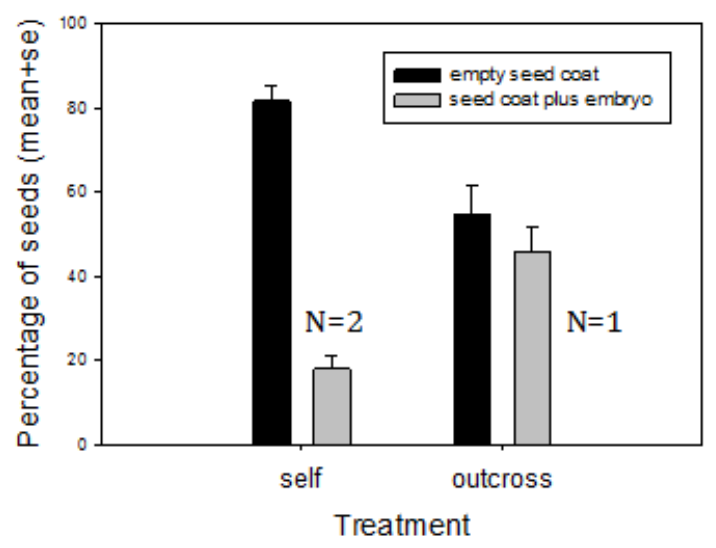

b)

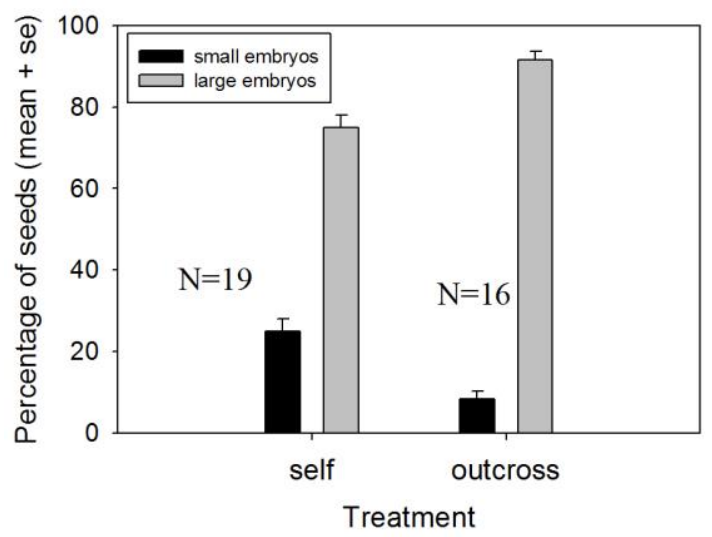

Figure 3.

https://mc06.manuscriptcentral.com/botany-pubs 


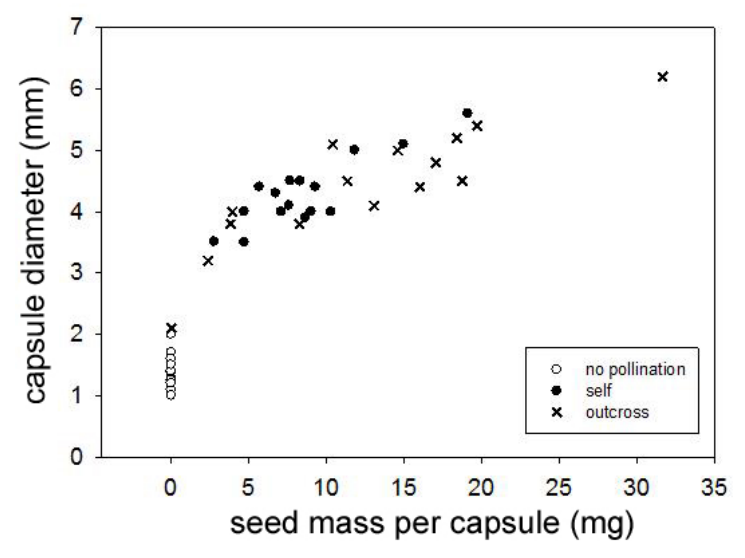

Figure 4. 
App Figure A1. Micrographs of seeds from hand-pollinations of Platanthera praeclara. A. Seed with a small embryo ( $<50 \%$ area inside seed coat). B. Seed with a large embryo ( $>50 \%$ area inside seed coat).

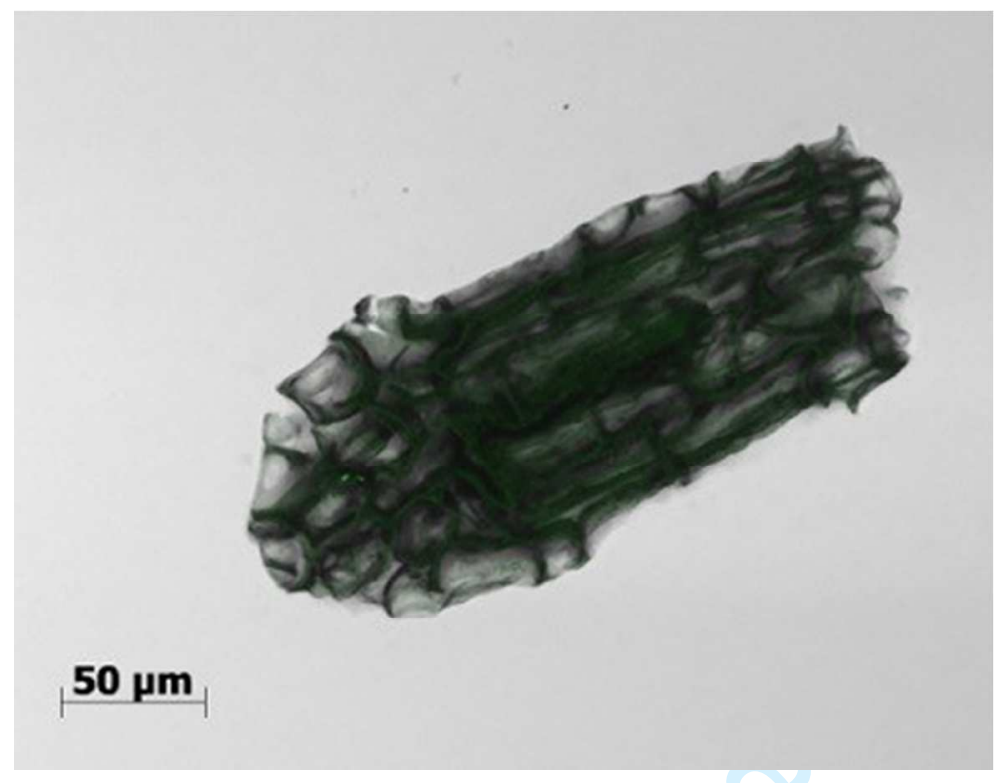

A.

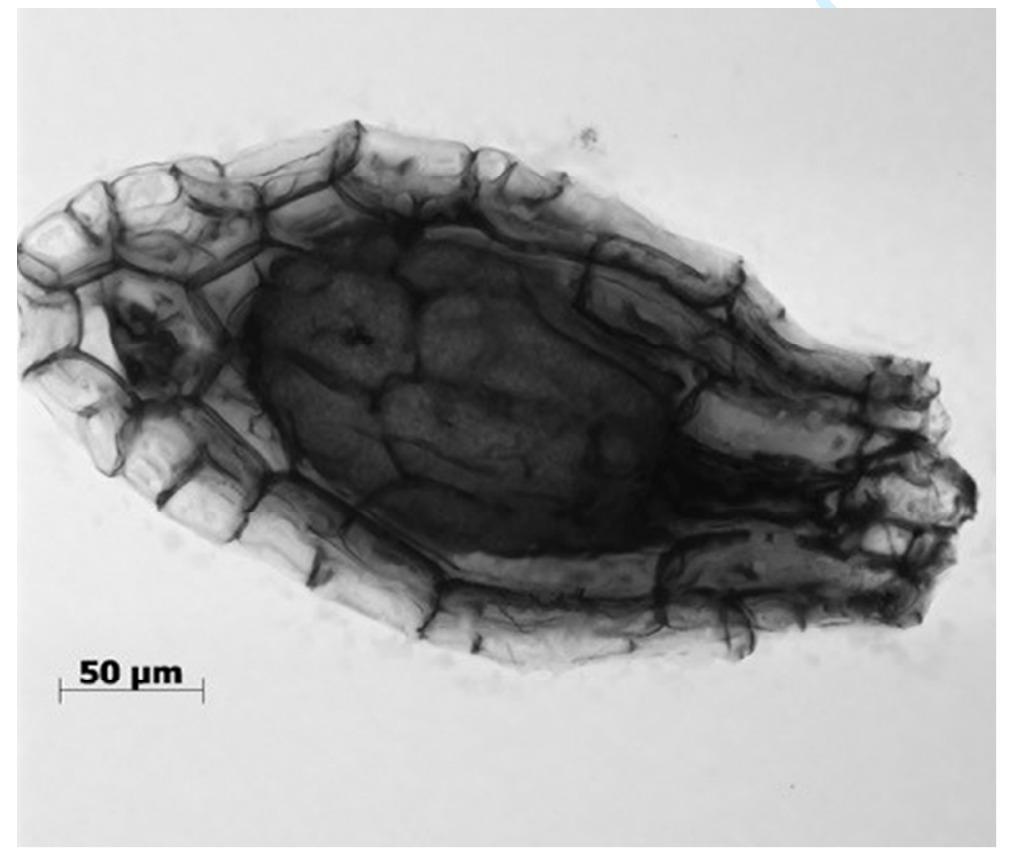

B. 